\title{
Analysis of urban flood using synthetic unit hydrograph (SUH) and flood mitigation strategies along way Halim River: a case study on Seroja street, Tanjung Senang District
}

\author{
Dian Pratiwi ${ }^{1 *}$ Arniza Fitri $^{1}$, Arlina Phelia $^{1}$, Nabila Annisa Amara Adma ${ }^{1}$, and Kastamto ${ }^{1}$ \\ ${ }^{1}$ Department of Civil Engineering, Faculty of Engineering and Computer Science, Indonesian Tecnocrat University, Bandar \\ Lampung, Lampung 35132, Indonesia
}

\begin{abstract}
In the urban area, flooding becomes the most common disaster that has not been resolved until today. The utilization of river border area into housing and lack of absorption area becomes the trigger factor of urban flooding, as what is happening around Way Halim River on Seroja street. In this area, floods often happen during the rainy season, with the latest events recorded on January $21^{\text {st }}$, 2021. Analysis of flood intensities and discharges can be parameters for the decision-making of flood mitigation strategies. This study aims to analyze the flood discharges along Way Halim River, Seroja street by comparing the flood discharges resulting from three analysis methods of Synthetic Unit Hydrograph (SUH) including Gama I SUH, Nakayasu SUH, and Snyder SUH. Finally, suitable flood mitigation strategies were also proposed in this study based on the flood discharges and rain intensities. The results showed that Nakayasu SUH had the highest peak flood discharge than Snyder SUH and Gama I SUH. Based on the results of the investigation of land suitability; and analysis of rainfall intensities and flood discharges, the proposed flood mitigation in Seroja street is by installing biopore infiltration holes along Seroja street for storing water and reducing the risk of flooding in the area.
\end{abstract}

\section{Introduction}

In Indonesia, flood events are always repeated every year, especially during the rainy season. Flood occurrences can be triggered by an increase in population density, climate change, and economic development in flood-prone areas [1-6]. In the urban area, floods are the main problem that causes financial, social, and environmental losses, especially in the areas that are prone to flood events. The density of population settlements and the use of river border areas into residential areas cause flooding that is commonly called urban flooding [7].

Flood control is related to flood mitigation [8-17]. The mitigation itself differs into non-structural mitigation and structural mitigation. The mitigation that is conducted with concepts, policy, plan, and operation on integrated urban flood disaster and risk management can achieve multiple goals such as water supply, groundwater recharge, and the improvement of the urban environment [19].

Related to urban areas and flood mitigation, there are several flood mitigation strategies in urban areas with high population density, limited water catchment areas, and poor drainage systems that can be applied. These are including infiltration wells, rainwater harvesting utilizing rain barrels, and biopore hole.

Infiltration wells can reduce surface runoff, but the effectiveness of the infiltration wells depends on the density and dimensions of the well [20]. Rainwater harvesting utilizing a rain barrel is significant to reduce flood peaks in a densely populated area [21]. Biopore holes as a method of water conservation based on soil permeability, rainfall intensity, depth of groundwater level, and volume of organic waste can also be one of the flood mitigation strategies in urban areas with the dimensions of the hole can be applied in narrow residential land [22,23].

In Bandar Lampung City, where the development areas reach $69.5 \%$ of the total area $(13,711.17 \mathrm{ha})$ in 2020 , faces a high level of flooding vulnerability due to changing the function of water catchment areas and river borders into housing or residential areas [24]. For example, in the area of Seroja street, Tanjung Senang District, Bandar Lampung City, floods events occur after the switching functions of the Way Halim Border River area into residential and lack of water catchment area. The biggest event of urban floods in Seroja street has been recorded on July $5^{\text {th }}, 2020$, and July $21^{\text {st }}, 2021$. The

* Corresponding author: dian.pertiwi@teknoret.ac.id 
floodwater level during the peak flood reached 30 to 55 $\mathrm{cm}$ in the area around Seroja street.

The existing conditions along way Halim river and the condition during the flood on Seroja street are shown in Figs 1 and 2.

Based on the conditions, it is necessary to analyze the intensities of rain and urban flood discharges along way Halim river. Besides, appropriate mitigation strategies in the catchment area of Way Halim river especially around Seroja street need to be proposed. Further, the information about rainfall intensities, flood discharges, and recommendations of the proper flood mitigation strategies in Seroja street can be important for the local community and local government in Bandar Lampung City.

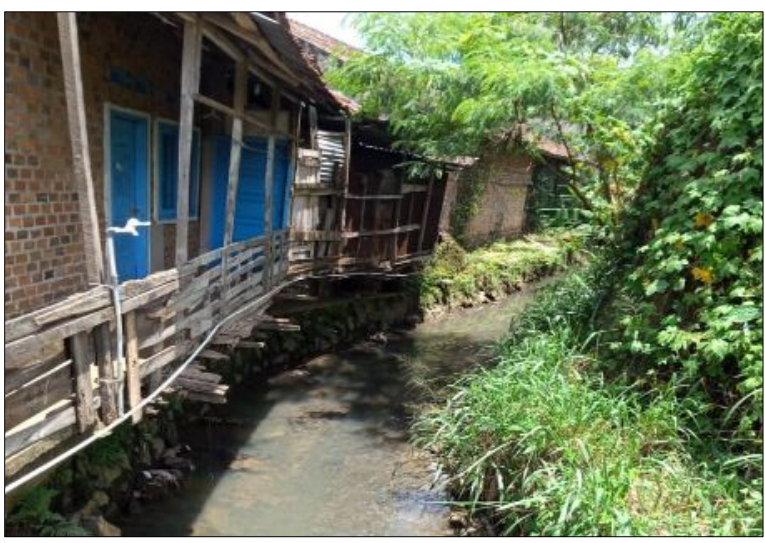

Fig. 1. Residential conditions along Way Halim River on Seroja Street.

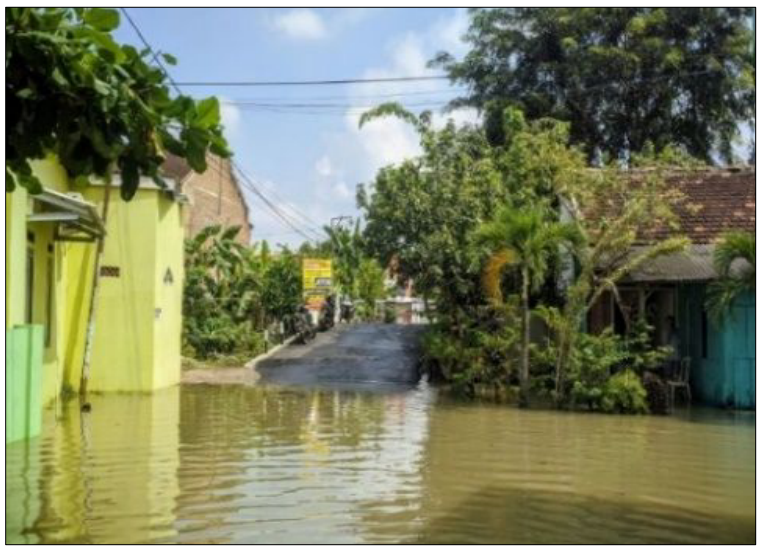

Fig. 2. The condition during a flood event in Seroja Street.

\section{Research Method}

\subsection{Study Area and Data Collection}

This study has been carried out along way Halim river, especially at Seroja street as shown in Fig. 3. In this study, data collections are including primary data and secondary data. Primary data was used to collect information about flood events that have been occurred around Seroja street. The secondary data are consisting of the area of the watershed, the characteristics of the watershed, and the rainfall data from 4 rainfall stations [RS) in the year 20112020 [Kemiling RS, Sukarame RS, Sumur Batu RS,
Sumur Putri RS). Fig. 4 shows the location of the rainfall stations in Way Halim catchment.
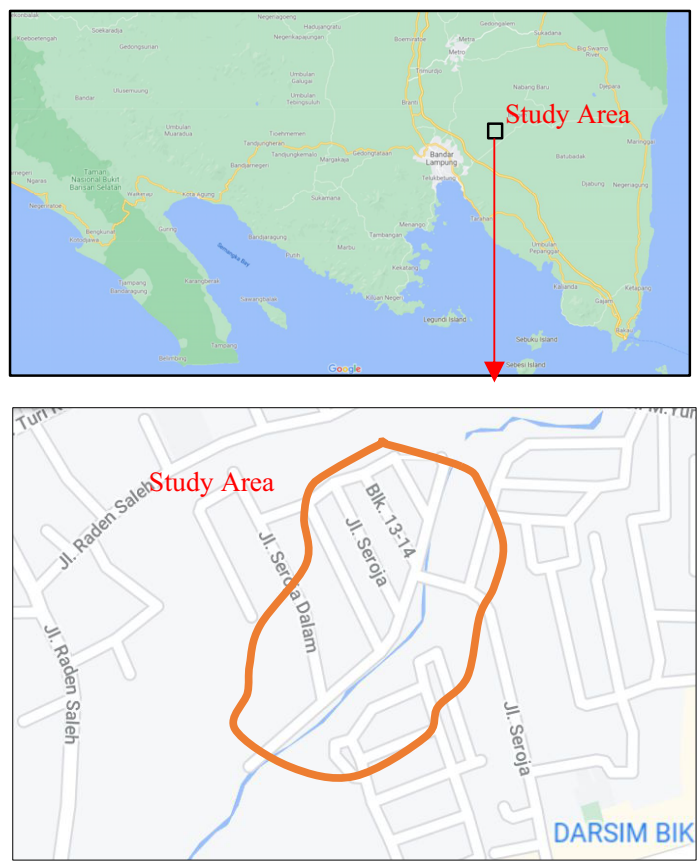

Fig. 3. Description of the study area

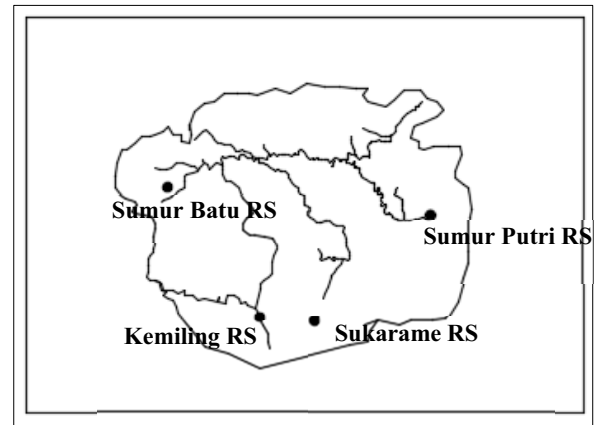

Fig. 4. Location of Rainfall Stations is Way Halim Catchment

\subsection{Data Analysis Method}

Data analysis involved in this study includes analysis of flood discharges, analyses of rainfall intensity, and analyses of urban flood mitigation strategies. The analysis stages include 1) rainfall area analysis using polygon Thiessen, 2) frequency distribution analysis using Log Pearson Type III, 3) statistical distribution for rainfall, rainfall intensity analysis, 4) discharge analyses using synthetic unit hydrograph [SUH), and 5) recommendation for suitable flood mitigation strategies around Seroja street, Tanjung Senang District, Bandar Lampung.

\subsubsection{Rainfall Area Analysis}

Rainfall measurements are made to obtain rain data which are usually only in one place, while in the analysis, it is necessary to use the average rainfall data for the watershed. To obtain the average rainfall data from a watershed with the requirement, there are at least 3 rain stations used in a watershed. Then, the average rainfall 
data can be obtained by using the Thiessen-Polygon method [25).

$$
\begin{aligned}
& P_{d}=\sum_{i=1}^{n} a_{i} \cdot P_{i} \\
& a_{i}=\frac{L i}{L}
\end{aligned}
$$

Where $P_{d}$ is the average rainfall in the watershed $(\mathrm{mm}), P_{i}$ is the rainfall for each station $(\mathrm{mm}), i$ is the station weight factor, $L_{i}$ is the area of each Thiessenpolygon $\left(\mathrm{km}^{2}\right)$ and $L$ is the area of the watershed $\left(\mathrm{km}^{2}\right)$.

\subsubsection{Frequency Distribution Analysis}

Log Pearson Distribution Analysis Type III is used in the hydrological analysis as a parameter to determine rainfall intensity for a certain return period. The requirement in this distribution is that the coefficient of skewness is not equal to 0 or $C s \neq 0$ (26).

\subsubsection{Statistical Distribution for Rainfall}

The rain statistical distribution used is Chi-Square and Kolmogorov-Smirnov statistic. The formula for the chisquare statistic is given by [26] :

$$
\mathrm{X}_{\mathrm{hit}}^{2}=\sum_{\mathrm{i}=1}^{\mathrm{k}} \frac{(\mathrm{EF}-\mathrm{OF})^{2}}{\mathrm{EF}}
$$

Where $K$ is calculated by the equation $1+3.22 \cdot \log n$, $O F$ is the observed value and $E F$ is the expected value. For the selected frequency distribution to be acceptable, the requirements that must be met are $X^{2}<X^{2}{ }_{c r}$. The $X^{2}{ }_{c r}$ value can be obtained by determining the significant level with degrees of freedom.

Kolmogorov-Smirnov (D) based on the largest difference of Relationship cumulative frequency $\left(F_{n}(x)\right)$ and Theoretical Cumulative Frequency $(F(x))$. Kolmogorov-Smirnov statistic formula is given by [26]:

$$
D_{n}=\left|F_{n}(x)-F(x)\right|
$$

\subsubsection{Synthetic Unit Hydrograph (SUH)}

Synthetic unit hydrograph (SUH) is a rainfall runoff model of a watershed, obtained from synthetic methods without using measured data. The SUH method used in this study including the Gama I SUH, Nakayasu SUH and Snyder SUH. With the equation given in Gama I SUH, as follows [27):

$$
\begin{aligned}
& \mathrm{B}=1,5518 \mathrm{~N}-0,14991 \mathrm{~A}-0,2725 \mathrm{SIM}-0,0259 \mathrm{~S}- \\
& 0,0733 \\
& \mathrm{Qp}=0,1836 \text { A. } 0,5884 . \mathrm{JN} \cdot 0,2381 . \operatorname{tr}-0,4008 \\
& \mathrm{tb}=27,4132 \text { tr. } 0,1457 \mathrm{~S}-0,0986 \mathrm{SN} .0,7344 \text { RUA. } 0,25 \\
& \mathrm{~K}=0,5671 \text { A. } 0,1798 \mathrm{~S}-0,1446 \mathrm{SF}-1,0897 \mathrm{D} \cdot 0,0452 \\
& \mathrm{QB}=0,4751 \mathrm{~A} \cdot 0,6444 \mathrm{D} \cdot 0,9430
\end{aligned}
$$

Where $N$ is the number of train stations, $A$ is the area of the watershed $\left(\mathrm{km}^{2}\right), S I M$ is the Symmetry Factor, $S$ is the average river slope, $B$ is the reduction coefficient, $S N$ is the source frequency, $R U A$ is the relative area upstream watershed $\left(\mathrm{km}^{2}\right), D$ is the drainage net density and $Q B$ is the base flow $\left(\mathrm{m}^{3} / \mathrm{s}\right)$. For time to peak $(t r)$, the related variables are river length $(L)$, Source factor $(S F)$, and Symmetry factor $(S I M)$. Calculation of the peak flood discharge of HSS Gama I $\left(Q_{p}\right)$ uses the $J N$ variable, defined as several river encounters. Then, the equation for Nakayasu SUH is as follows [27] :

$$
\begin{aligned}
& Q_{p}=\frac{C A R}{3,6(0,3 T p+T 0,3)} \\
& T_{P}=t g=0,8 \mathrm{tr} \\
& t g=0,21 L^{0,7}(\text { for } \mathrm{L}<15 \mathrm{~km}) \\
& t g=0,4+0,058 L(\text { for } \mathrm{L}>15 \mathrm{~km}) \\
& T_{0,3}=\alpha \cdot \operatorname{tg} \\
& Q t=\left(\frac{t}{T_{p}}\right)^{2,4} \cdot Q_{P}
\end{aligned}
$$

Where QP is the peak flood discharge (m3/s), R is the unit rain ( $\mathrm{mm}), \mathrm{C}$ is the coefficient of drainage, TP is the period from early rain to time to peak of flood discharge (hours). 0.3TP is the time it takes for the discharge to decrease, from peak discharge to $30 \%$ of the peak discharge, $\mathrm{Tg}$ is the time of concentration (hours) and $\alpha$ is the hydrograph parameter (the value is between 1.5-3.0). Other equations used in Nakayasu SUH are as follows [27] :

$$
\begin{aligned}
& Q_{t}=Q_{P}\left(\frac{t}{T_{P}}\right)^{2,4} \quad \text { for } 0 \leq t \leq T_{p} \\
& Q_{t}=Q_{P} 0,3^{\left[\frac{t-T_{P}}{T_{0,3}}\right]} \quad \text { for } T_{p} \leq t \leq\left(T_{P}+T_{0,3}\right) \\
& Q_{t}=Q_{P} 0,3^{\left[\frac{t-T_{P}+0,5 T_{0,3}}{1,5 T_{0,3}}\right]} \text { for }\left(T_{P}+T_{0,3}\right) \leq t \leq\left(T_{P}+T_{0,3}+\right. \\
& \left.1,5 T_{0,3}\right) \\
& Q_{t}=Q_{P} 0,3^{\left[\frac{t-T_{p}+0,5 T_{0,3}}{2 T_{0,3}}\right]} \text { for } t>\left(T_{P}+T_{0,3}+1,5 T_{0,3}\right)
\end{aligned}
$$

For Snyder SUH given by the following equation:

$$
\begin{aligned}
& t_{p}=C_{t}\left(L \cdot L_{c}\right)^{0,3} \\
& t_{e}=0,278 \frac{C_{p \cdot A}}{t_{p}} \\
& T_{b}=5,0\left(T_{p}+\frac{t_{r}}{2}\right)
\end{aligned}
$$

\subsubsection{Flood Mitigation}

After analyzing the flood discharge and rainfall intensity, appropriate structural mitigation steps were taken. Because the research area is a densely populated residential area and space requirements are very limited, it is necessary to optimize space utilization. The Biopore infiltration hole technique is one of the solutions to overcome flooding. Biopore Infiltration Hole can be a water reservoir and flood control that can be applied in narrow residential areas.

\section{Result and Discussion}

\subsection{The Average of Annual Rainfall}

Annual rainfall gave by calculating the maximum rainfall of 2011-2020 in Garuntang Sub Catchment area around Seroja street and the coefficient of polygon Thiessen. The coefficient of polygon Thiessen is given 
in Tabel 1., while the average annual rainfall is given in Table 2.

Table 1. Polygon Thiessen Coefficient

\begin{tabular}{|c|c|c|}
\hline No. & Rainfall Station & $\begin{array}{c}\text { Thiessen } \\
\text { Coefficient } \\
(\boldsymbol{\alpha})\end{array}$ \\
\hline 1 & Kemiling RS & 0,175 \\
\hline 2 & Sukarame RS & 0,137 \\
\hline 3 & Sumur Batu RS & 0,379 \\
\hline 4 & Sumur Putri RS & 0,309 \\
\hline \multicolumn{2}{|l}{} & 1,000 \\
\hline
\end{tabular}

Table 2. Annual Average Rainfall using Polygon Thiessen Method

\begin{tabular}{|c|c|c|}
\hline No & Tahun & $\begin{array}{c}\text { Average } \\
\text { Rainfall } \\
\text { (mm) }\end{array}$ \\
\hline 1 & 2020 & 101.7461 \\
\hline 2 & 2019 & 61.0729 \\
\hline 3 & 2018 & 51.3745 \\
\hline 4 & 2017 & 89.7055 \\
\hline 5 & 2016 & 37.1122 \\
\hline 6 & 2015 & 40.5835 \\
\hline 7 & 2014 & 42.2426 \\
\hline 8 & 2013 & 71.5106 \\
\hline 9 & 2012 & 20.3927 \\
\hline 10 & 2011 & 196.9144 \\
\hline
\end{tabular}

\subsection{Design Rainfall and rainfall Intensity}

Table 3. Statistical Parameters for Determining the Type of Distribution

\begin{tabular}{|c|c|c|c|}
\hline $\begin{array}{c}\text { Type of } \\
\text { Distributi } \\
\text { on }\end{array}$ & Parameter & $\begin{array}{c}\text { Analysis } \\
\text { result }\end{array}$ & $\begin{array}{c}\text { Informatio } \\
n\end{array}$ \\
\hline $\begin{array}{l}\text { Normal } \\
\text { Distributio } \\
\mathrm{n}\end{array}$ & $\begin{array}{l}\mathrm{Cs}=0 \\
\mathrm{Ck}=3\end{array}$ & $\begin{array}{l}\mathrm{Cs}=1.91 \\
\mathrm{Ck}=6.50\end{array}$ & $\begin{array}{c}\text { Not } \\
\text { accepted }\end{array}$ \\
\hline Gumbel & $\begin{array}{l}\mathrm{Cs}= \\
1.1396 \\
\mathrm{Ck}= \\
5.4002 \\
\end{array}$ & $\begin{array}{l}\mathrm{Cs}=0.13 \\
\mathrm{Ck}=38.67\end{array}$ & $\begin{array}{c}\text { Not } \\
\text { accepted }\end{array}$ \\
\hline $\begin{array}{l}\text { Log } \\
\text { Normal }\end{array}$ & $\begin{array}{l}\mathrm{Cs}(\mathrm{InR})= \\
0 \\
\mathrm{Ck}(\mathrm{InR})= \\
0\end{array}$ & $\begin{array}{l}\mathrm{Cs}=2.33 \\
\mathrm{Ck}=7.68\end{array}$ & $\begin{array}{c}\text { Not } \\
\text { accepted }\end{array}$ \\
\hline $\begin{array}{l}\text { Log } \\
\text { Pearson } \\
\text { Type III }\end{array}$ & Others & $\begin{array}{l}\mathrm{Cs}=0.32 \\
\mathrm{Ck}=0.62\end{array}$ & accepted \\
\hline
\end{tabular}

Table 3. show the value of $C_{s}$ and $C_{k}$ as the parameter for rainfall distribution, that has been calculated from each distribution.
Based on the statistical parameter results, it can be seen that Log Pearson Type III is accepted as the design rainfall. With 5, 25, 50, and 100 years return period.

Table 4. Design Rainfall using Log Pearson Type III

\begin{tabular}{|c|c|}
\hline $\begin{array}{c}\text { Return Period } \\
\text { (years) }\end{array}$ & $\begin{array}{c}\text { Design Rainfall } \\
\text { (mm) }\end{array}$ \\
\hline 5 & 96.716 \\
\hline 25 & 179.378 \\
\hline 50 & 223.246 \\
\hline 100 & 273.129 \\
\hline
\end{tabular}

From the design rainfall, rainfall intensity can be obtained. The rainfall intensity in minute used mononobe formula in 2, 5, 25, 50 and 100 years return period given in Fig. 5.

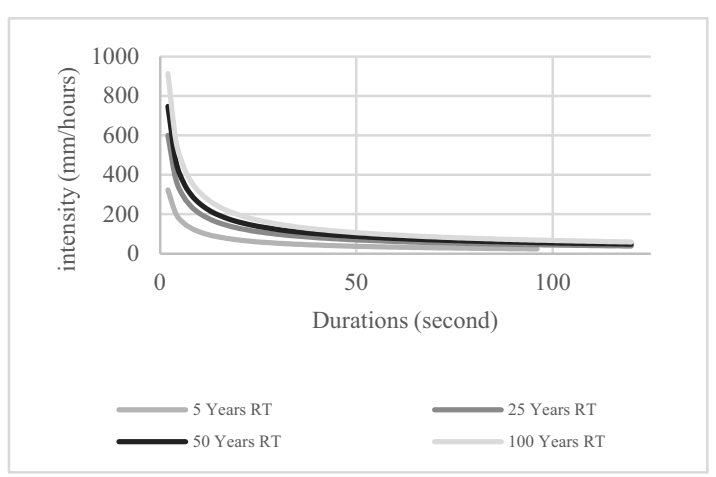

Fig. 5. IDF Curve using Mononobe Formula

IDF curve shows the intensity of Way Halim river around Seroja street. The time concentration of the IDF curve at 1.027 hours, with an intensity of $32.94 \mathrm{~mm}$. The intensity is used as the parameter for the mitigation using a biopore infiltration hole.

\subsection{Syntetic Unit Hydrograf (SUH)}

The synthetic Unit Hydrograph (SUH) method was used to identify the flood discharges. The result from Gama I SUH, Nakayasu SUH, and Snyder SUH has given in fig (Fig 6, Fig 7, and Fig 8).

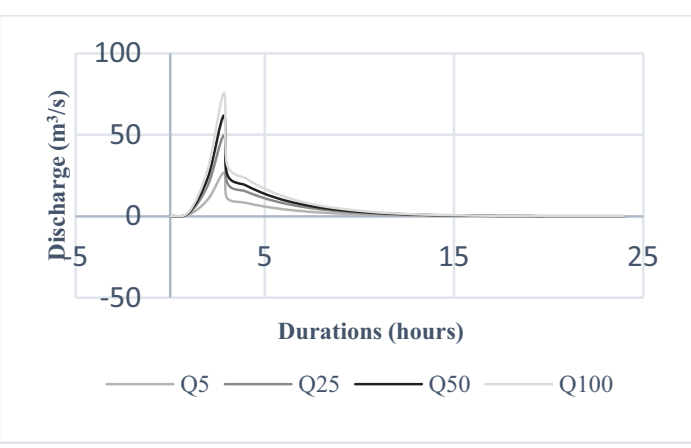

Fig. 6. Gama I SUH for different Return Period. 


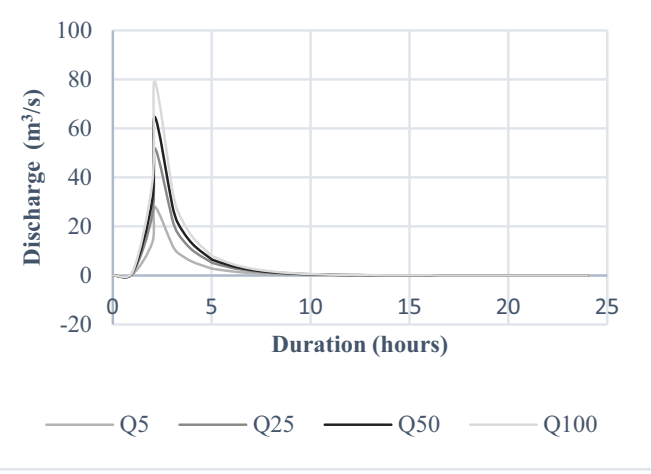

Fig. 7. Nakayasu SUH for Different Return Period

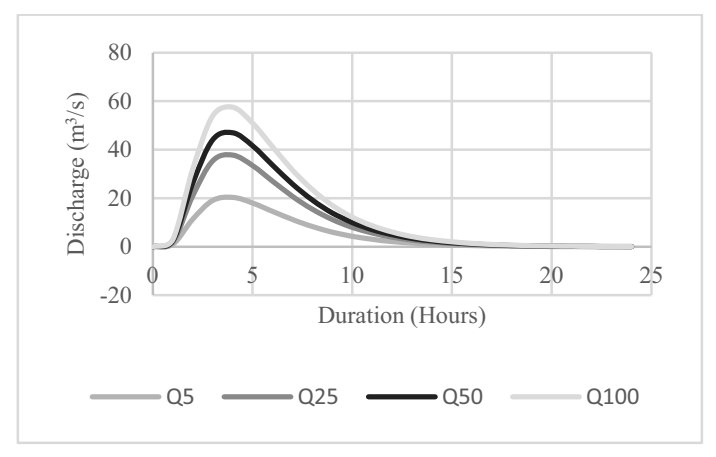

Fig. 8. Snyder SUH for Different Return Period

\subsection{Biopore Hole Infiltration}

Mitigation planning on Seroja street is carried out by applying biopore holes in residential areas. Biopore hole design by using a pipe with $100 \mathrm{~mm}$ hole diameter and 1meter height of biopore pipe. Hole water infiltration rate assumed as 180 liter/hours. The parameter that is used in biopore hole using intensity in 5 years return period is $32.94 \mathrm{~mm}$. The biopore hole infiltration plan can be seen in the following table (Table 5).

Table 5. Biopore Hole Infiltration plan in various residential areas.

\begin{tabular}{|c|c|c|}
\hline \multicolumn{2}{|c|}{ Tight field area $\left(\mathbf{m}^{2}\right)$} & $\begin{array}{c}\text { Number of } \\
\text { Biopore } \\
\text { Hole }\end{array}$ \\
\hline \multirow{3}{*}{ Existing } & 76 & 14 \\
\cline { 2 - 3 } & 78 & 14 \\
\cline { 2 - 3 } & 80 & 15 \\
\hline \multirow{4}{*}{ Assumption } & 36 & 7 \\
\cline { 2 - 3 } & 45 & 8 \\
\cline { 2 - 3 } & 54 & 10 \\
\cline { 2 - 3 } & 72 & 13 \\
\cline { 2 - 3 } & 120 & 22 \\
\hline
\end{tabular}

\section{Conclusion}

Urban flooding is one of the disasters that should be a concern for urban communities. By utilizing the border area of the river into housing and turning water infiltration areas into residential areas can be the triggering factor for urban flooding. During the rainy season, the peak discharge by using Nakayasu SUH for 5, 25, 50, and 100 years Return Period gave the highest value than Gama I SUH and Snyder SUH. The results were $28.041 \mathrm{~m} 3 / \mathrm{s}$, $52.008 \mathrm{~m} 3 / \mathrm{s}, 64.727 \mathrm{~m} 3 / \mathrm{s}$, and $79.190 \mathrm{~m} 3 / \mathrm{s}$ respectively. This peak discharge value is used as a recommendation for the local government in making decisions regarding mitigation that can be carried out along the Way Halim River.

Related to the mitigation that can be done by residents, several steps can be taken to reduce urban flooding. One of them is by applying biopore infiltration holes. The biopore infiltration hole can be applied to densely populated areas with limited water catchment in residential areas. Although biopore holes do not provide quick results in overcoming floods, with the function of biopore holes that can absorb rainwater runoff during the rainy season, it can be a solution step in overcoming urban flooding as well as water catchment areas that can be applied to densely populated housing.

The author expresses many thanks to Universitas Teknokrat Indonesia for supporting in the process of completing this study.

\section{References}

1. D. Pratiwi, R.O. Sinia, A. Fitri, Increasing Public Knowledge of Porous Drainage which functions as a place for rainwater infiltration, J Soc Sci Technol Community Serv.;1(2) (2020)

2. K.N.A. Maulud, A. Fitri, W.H.W.M. Mohtar, W.S.W.M. Jaafar, N.Z. Zuhairi, M.K.A Kamarudin, A study of spatial and water quality index during dry and rainy seasons at Kelantan River Basin, Peninsular Malaysia. Arab J Geosci.;14 (2):1-19 (2021)

3. A. Fitri, K. Nizam, A. Maulud, F. Rossi, F. Dewantoro, N.Z. Zuhairi, Spatial and Temporal Distribution of Dissolved Oxygen and Suspended Sediment in Kelantan River Basin. In: In 4th International Conference on Sustainable Innovation 2020-Technology, Engineering, and Agriculture (ICoSITEA 2020). Atlantis Press.; 51-4 (2021)

4. A. Fitri, K.N.A. Maulud, D. Pratiwi, A. Phelia, F. Rossi, N.Z. Zuhairi, Trend Of Water Quality Status In Kelantan River Downstream, Peninsular Malaysia. J Rekayasa Sipil (2020)

5. A. Fitri, Z.A Hasan, A.A Ghani. Determining the Effectiveness of Harapan Lake as Flood Retention Pond in Flood Mitigation Effort. In: In Proceedings of 2011 4th International Conference on Environmental and Computer Science (ICECS 2011). (2011)

6. S.H. Lai, A. Fitri. Application of SWAT Hydrological Model to Upper Bernam River Basin (UBRB), Malaysia. IUP J Environ Sci; 5 (2) (2011)

7. M. Irwansyah, C. Nursaniah, L. Qadri, Alternatives for Settlement Area Management of Meureudu River watersheds towards Flood Mitigation (Case Study of Meureudu City Center, Pidie Jaya-Aceh), 63-71 (2017) 
8. H. Chen, L. Yao, A. Fitri, The influence mechanism research of inflow temperature in different time scale on the water temperature structure. In: IOP Conference Series: Earth and Environmental Science, 12058 (2019)

9. L. Yao, X. Huang, A. Fitri, Influence scope of local loss for pipe flow in plane sudden expansions. In: IOP Conference Series: Earth and Environmental Science, 12056 (2019)

10. D. Pratiwi, A. Fitri, Analysis of the Potential for Tsunami Wave Propagation on the West Coast of Lampung, Indonesia. J Tek Sipil ITP. 2021;8 (1), 29_ 37.

11. L. Yao, J. Li, S. Shi, A. Fitri, Simulation of take-off angle of a ski jump energy dissipater. In: IOP Conference Series: Earth and Environmental Science, 12057 (2019)

12. A. Fitri, R. Hashim, Motamedi S. Estimation and validation of nearshore current at the coast of Carey Island, Malaysia. Pertanika J Sci Technol 25 (3), 1009-18 (2017)

13. A. Fitri, R. Hashim, S. Abolfathi, K.N.A. Maulud, Dynamics of sediment transport and erosiondeposition patterns in the locality of a detached lowcrested breakwater on a cohesive coast. Water (Switzerland), 11 (8) (2019)

14. F. Arniza, Hydro-morphodynamic responses of the detached breakwater in mangrove rehabilitation project/Arniza Fitri. University of Malaya (2018)

15. A. Fitri, L. Yao, B. Sofawi, Evaluation of mangrove rehabilitation project at Carey Island coast, Peninsular Malaysia based on long-term geochemical changes. In: IOP Conference Series: Earth and Environmental Science, 12055 (2019)

16. R. Hashim, C Roy, S. Shamshirband, S. Motamedi, A.Fitri, D. Petković, et al. Estimation of WindDriven Coastal Waves Near a Mangrove Forest Using Adaptive Neuro-Fuzzy Inference System. Water Resour Manag, 30 (7), 2391-404 (2016)

17. R. Hashim, A. Fitri, S. Motamedi, A.M. Hashim. Modeling of coastal hydrodynamic associated with coastal structures: A review. Malaysian J Sci. 32 (4), 149-54 (2013)
18. A. Fitri, R. Hashim, K. Song Il, S. Motamedi. Evaluation of Morphodynamic Changes in the Vicinity of Low-Crested Breakwater on Cohesive Shore of Carey Island, Malaysia. Coast Eng J. 57 (4), 1550023 (2015)

19. T. Tingsanchali, Urban flood disaster management. Procedia Eng, 32:25-37 (2012)

20. D. I Kusumastuti, D. Jokowinarno, S.N. Khotimah, C. Dewi, F. Yuniarti, Infiltration well to reduce the impact of land-use changes on flood peaks: a case study of Way Kuala Garuntang catchment, Bandar Lampung, Indonesia. Hydrol Earth Syst Sci Discuss. 11 (5), 5487-513 (2014)

21. D. Jokowinarno, D.I Kusumastuti, Rainwater Harvesting for Flood Peak Reduction in Way Awi Catchment, Indonesia. Int J GEOMATE, 18 (70), 246-51 (2020)

22. N.I. Khusna, S. Amin, F.Y. Efrianinrum,A. Bashith, The effect of using biopore on soil fertility in karst area, District of Besuki, Tulungagung Regency. IOP Conf Ser Earth Environ Sci. 485 (1):100-4 (2020)

23. M.H. Syahruddin, Amiruddin, H. Halide, Sakka, Makhrani, Groundwater Conservation with Hole Infiltration of Biopore Cube. IOP Conf Ser Earth Environ Sci, 279 (1) (2019)

24. R. Wulandari, Supriatna, T. L Indra, A simulation model for urban development in Bandar Lampung City, Lampung, Indonesia. IOP Conf Ser Earth Environ Sci, 248(1). (2019)

25. N. Faisal, A. Gaffar, Development of Pakistan's s New Area Weighted Rainfall Using Thiessen Polygon Method. Pakistan J Meteorol. 9 (17), 10716 (2012)

26. M Farooq, M. Shafique, M.S. Khattak, Flood frequency analysis of river swat using Log Pearson type 3, Generalized Extreme Value, Normal, and Gumbel Max distribution methods. Arab J Geosci, 11 (9) (2018)

27. T. Marhendi, Fathurohman. Analysis of Flood Discharges of Serayu River at Serayu Barrage using HSS Gama I and Nakayasu Models. IOP Conf Ser Mater Sci Eng. 771(1) (2020) 